\title{
INFORMATIONAL ASPECT OF MODERN TECHNICAL EDUCATIONAL PROCESS IN THE HIGHER SCHOOL SYSTEM
}

\author{
Volkova Ekaterina Alexandrovna ${ }^{1}$, Frolova Elena Vladimirovna ${ }^{2}$, Likhoradova Irina \\ Nikolaevna $^{3}$, Volkov Sergei Nikolaevich ${ }^{4}$
}

\begin{abstract}
${ }^{1}$ Doctor of Historical Sciences, Associate Professor of the Department of Philosophy, Sociology and History, Voronezh State Technical University Voronezh, Russia; E-mail: volkne@bk.ru ${ }^{2}$ Candidate of Philosophy, Associate Professor of the Department of Philosophy, Sociology and History, Voronezh State Technical University Voronezh, Russia; E-mail: frolov-elen@yandex.ru ${ }^{3}$ Candidate of Historical Sciences, Associate Professor of the Department of Philosophy, Sociology and History, Voronezh State Technical University Voronezh, Russia; E-mail: lihoradova@list.ru ${ }^{4}$ Bachelor, Voronezh State Technical University, 20 years of October Street, 84, Voronezh, Russia, e-mail: Sergeyvolkov2001@gmail.com
\end{abstract}

\begin{abstract}
The article is devoted to the analysis of the influence of informatization of society on the mechanisms of functioning and implementation of the higher education system. The authors highlight the basic values of the information society, such as knowledge; qualification; independence of thinking; ability to work with information and make a decision. The global epidemiological challenge (COVID-19) has affected absolutely all spheres of life in modern society, including the higher education system. The purpose of this study: is to analyze the impact of the "cavid crisis" on the domestic system of higher education in general and on modern technical education in particular.
\end{abstract}

Keywords: informatization, information, higher education system, training, epidemiological challenge, information culture, creative potential.

\section{INTRODUCTION}

In recent decades, modern mankind has joined the general historical process called informatization. This is due to the fact that humanity is aware of the limited natural (natural) resources of its habitat, and secondly, the emergence of global problems (for example, energy, environmental), the solution of which is impossible by the previous means. Information is becoming the main resource for the development of the world community and significantly affects the development of other industries and spheres of life: science, technology, social spheres (cultural communication between people, education).

The main values of the information society are: knowledge; qualification; independence of thinking; the ability to work with information and make a reasoned decision on this basis; awareness not only in a narrow professional field, but also in related fields. However, the global epidemiological challenge (COVID-19) has put the whole world on the brink of survival. Its essence lies in the fact that a global problem has endangered not only the existence of the person himself, regardless of gender and race, level of well-being, etc., but also for the first time, in a long time, has managed to demoralize the consciousness of each individual person.

The purpose of our research is to analyze the consequences of the "cavid crisis" for the domestic system of 
higher education in general and for modern technical education in particular. Fast transition to online, urgent mobilization of the entire teaching and learning system, lack of live communication, elimination of the concept of "student life", differentiation of teachers up to 65 and after 65 . All of the above indicated the problem of correlation of the information space with the existing realities of the functioning of higher educational institutions. The state actively intervenes in this process and legislatively formalizes and regulates the processes that are taking place in Russia and the world.

In our work, we relied on the following documents from the legislation of the Russian Federation:

1.Strategy for a developed information society in the Russian Federation ", approved by President of the Russian Federation 07.02.2008 No. Pr-212.

2. Order of the Government of the Russian Federation of 20.10.2010 No. 1815-r. "On the State Program of the Russian Federation" Information Society (2011-2020) ".

3. Decree of the Government of the Russian Federation of October 4, 2000 No. 751 "National doctrine of education in the Russian Federation until 2025".

\section{DISCUSSION AND RESULTS}

Currently, this topic is very popular and relevant, and all studies can be conditionally divided into three groups. The first group includes the works of S.A. Beshenkov, O.A. Kozlov, M.P. Lapchik, M.I. Makhmutova, A.B. Petrova, I.V. Robert, N.V. Sofronov, C.B. Simonovich V.A. Kaimin, who investigate the ways, methods and methods of forming informational training of students and postgraduates.

The second group includes the works of C.B. Vorobyova, L.V. Gaidarenko, E.V. Danilchuk, N.B. Zinovieva, V.A. Kaimina, H.A. Lavrinenko, L.K. Medzyanovskaya, N.V. Ogurtsova, who focused their research on the essence of information culture in the student environment.

The third group examines the pedagogical and organizational conditions for the formation of the information culture of students of different directions and educational levels. They are described in the scientific works of O.V. Artyushkina, V.T. Galchenko, I. Yu. Efimova, A.B. Shablova and others. In these works, the authors analyze the features of students' activities, investigate the requirements that they must meet, reveal patterns and consider technologies for improving the educational process in the education system.

The fundamental statement for us is the components of the information culture of a modern student. Information culture is formed among university students in the process of teaching computer science and using modern information and communication technologies in the development of general professional and special disciplines.

A special role in this is played by the pedagogical conditions for the formation of the information culture of a graduate of a technical university. It includes the following components: 1) a state order for a comprehensively developed graduate of a technical university, capable of adapting to any information transformations; 2) the requirements of the international community for the formation of a student of a technical university who has all information competencies and is able to quickly integrate into the global professional information environment; 3 ) the formation of the creative nature of engineering activities in the new information environment.

We consider the following criteria for a student's information culture:

- Awareness of the lack of information;

- The ability to formulate your need for information;

- Possession of the skills to effectively search for the necessary information;

- The use of the entire set of information resources when searching for missing information;

- Skills in working with information retrieval systems;

- The ability to process, analyze and evaluate information;

- The ability to create qualitatively new information;

- The ability to communicate with information;

- Computer literacy.

Let us consider these factors using the example of a specific higher educational institution that trains 
engineering personnel. A modern student - a future engineer, must use information and communication support in his professional activities, develop creative and research abilities. From the point of view of the authors, this task should go through the following stages.

1) The world outlook stage of the system of formation of information culture of students of a technical university, consisting of a target, meaningful, organizational-procedural, evaluative-productive component, revealing the theoretical essence and logic of the integral multi-level process of formation and development of information culture of a student of a technical university.

2) Technical stage - direct engineering education, which is implemented on the basis of curricula and educational standards based on the ability to perceive the world as a system of direct and reverse informational links, freely orienting in the information society.

3) The creative stage is the creation of a fundamentally new product that implements the creative competence of the future engineer, high productivity, based on a system of skills and abilities developed on their basis for the use of information and communication technologies.

4) Information stage - the introduction and distribution of a product at various levels of the information space, a developed level of information style of thinking, which ensures the processes of perception, structuring and decoding of information of a professional nature in order to assimilate high-tech technologies and introduce them into production.

A number of researchers, considering the contradictory nature of the development of information culture, believe that there is a danger of the possibility of a person's complete dependence on the information "monster" he has created. A special role, in their opinion, is acquiring the construction of intelligent information systems based on the processing of fuzzy data, which make it possible to most adequately model the qualitative side of the reasoning of specialists related to making managerial decisions. Overall, we share this statement.

\section{CONCLUSION}

A special role in the informatization of society undoubtedly belongs to the education system, since education acts, on the one hand, as a consumer of information, on the other, as a creator of new information technologies (through highly qualified personnel). Since the ability to work with information becomes one of the priorities for a modern person, the education system is designed to form the student's ability to think critically, starting from school (critical thinking is characterized by knowledge, comprehension, application, analysis, synthesis, evaluation). Education, flexibility of thinking, the ability to navigate in a huge flow of information become significant values for a person throughout his life. These values are also significant for society, since the rapid development of technologies in all areas of science, culture, production involves the use of the creative potential of educated people not only in the field of management, but also for the maintenance of technology.

Therefore, the informatization of education is considered as one of the priority directions of informatization of society. The informatization of education is understood as the process of providing the education sector with methodology, technology and practice for the development and optimal use of modern IR technologies, focused on the implementation of psychological and pedagogical goals of training and education, and used in comfortable and health-saving conditions. Under the influence of informatization of society, significant changes are taking place in the mechanism of functioning and implementation of the higher education system.

So, informatization initiates the following processes: improving the mechanisms of management of the education system based on: use of automated data banks of scientific and pedagogical information, information and methodological materials, communication networks; improvement of the methodology and strategy for the selection of content, methods and organizational forms of training and education, corresponding to the tasks of the student's personality development in the context of the informatization of society; creation of methodological learning systems focused on the development of the intellectual potential of the student, on the formation of skills to independently acquire knowledge, carry out information and educational, experimental and research activities, various types of joint activities for information processing; creation and use of computer testing, diagnosing methods for monitoring and assessing the level of knowledge of students.

The functioning of the higher education system has undergone even greater changes as a result of the COVID-19 pandemic. The shift to digital and distance learning has spawned a new wave of innovation that will have profound implications for humanity. Changing the relationship between citizens, government and 
business will also lead to a transformation of the structure of society and the economy, and the education system. It is already becoming clear today that the rate of economic growth, labor productivity and human development will increasingly be determined by the level of integration into the digital economy.

The Russian Federation faces a global task not only not to lag behind, but also to lead in this direction. We can already note the first steps in this direction: in September 2020, a large-scale experiment began in Russia to introduce a digital educational environment (DSP) into the education system. It is expected that during the implementation of the project, the target DSP model will be implemented throughout the country by 2024. In the long term, the state faces the task of creating a safe educational environment and a national electronic educational platform, overcoming barriers to international interaction in the field of education and training. .

\section{REFERENCE LIST}

Amirova S.S. (1996) Improving the self-organization of participants in the educational process in the context of lifelong education: author. dis. ... doct. ped. sciences. - Kazan.-28 p (in Russ).

Ashmarov I.A., Bobrovnikova M.A., Volkova E.A. (2016). On state policy in the sphere of regional education. Region: systems, economics, management. Pp.90-97. (in Russ).

Ashmarov I.A., Volkova E.A., Frolova E.V (2015) To the question of formation of trends in the higher education system in the framework of modern globalization processes. Modern problems of science and education.. No. 1-1. Pp 975 - 977 (in Russ).

Bronnikova L.M. (2016) Some aspects of the formation of a student's information culture // Modern problems of science and education. - No. 2 .; URL: http://science-education.ru/ru/article/view?id=24181 (date of access: 02/09/2021) (in Russ)..

Bulanova M. V. (2004) Pedagogy and psychology of higher education: textbook. stipend. Rostov-on-Don: Phoenix. 544 p. (in Russ).

Chekmeneva T.G., Ershov B.A., Trubitsyn S.D., Ostapenko A.A. (2020) Chinas Information Security Strategy: Political and Technical Aspects. Bulletin Social-Economic and Humanitarian Research. Volume 7. Number 9. Pp. 78 - 97. doi: 10.5281/zenodo.3911320 (in Russ).

Ershov B.A. (2010) The Russian Orthodox Church and secular power in the Voronezh province in the XIX early XX centuries. GOU VPO "Voronezh State Technical University". Voronezh. 167 p. (in Russ).

Ershov B.A. (2010) The system of spiritual education in Voronezh province in the 19th century. Education and Society. №. 5 (64). Pp. 105-108. (in Russ).

Ershov B.A., Fursov V.N. (2018) The Russian Church in the State Mechanism of Russia. Bulletin SocialEconomic and Humanitarian Research. № 1. Pp. 32-37. (in Engl).

Ershov B.A., Perevozchikova L.S., Romanova E.V. (2019) Globalization and Intensification of Spiritual Values in Russia in the Philosophical Aspect. 6th International Conference on Education and Social Sciences Abstracts \& Proceedings. Pp. 208-212. (in Engl).

Ershov B.A., Perevozchikova L.S., Romanova E.V., Ashmarov I.A. (2019) The Concept of Spirituality in Social Philosophy. Smart Innovation, Systems and Technologies. T. 139. Pp. 688-694. (in Engl).

Library of abstracts and dissertations in pedagogy http://nauka-pedagogika.com/pedagogika-13-0001/dissertaciya-mnogourovnevaya-sistema-formirovaniya-informatsionnoy-kultury-studentovtehnicheskogo-vuza\#ixzz6lbAablQw (in Russ).

Logunova L. (2001) Source and mystery of personality // Higher education in Russia. - No. 6. - P. 606 (in Russ).

Vitiska N.I., Sharanova S.I. (2011) Research of an intellectual system for combining the interests of teachers and students in the implementation of professional education // Informatization and communication. No. 3. - P. $72-76$ (in Russ).

Volkova E.A., Frolova E.V. (2016). Conditions for increasing the quality of the system of Russian higher education at the modern stage. // Actual problems of professional education: goals, objectives and 
prospects for development. collection of scientific articles based on the materials of the 14th allRussian correspondence scientific and practical conference. Pp.186-192. (in Russ).

Volkova E.A., Frolova E.V. (2017) Features of teaching humanities disciplines in technical universities (on the example of vstu) // Actual problems of vocational education: goals, objectives and development prospects. Collection of scientific articles based on the materials of the 15th all-Russian correspondence scientific-practical conference. Voronezh branch of the Russian Academy of National Economy and Public Administration under the President of the Russian Federation. Pp. 72-76. (in Russ).

Zagrenkova L.V. (1997) Fundamentals of pedagogical technologies // Higher education in Russia. - No. 4 (in Russ).

Zimnyaya I.A. (1997) Pedagogical psychology. - M.- p. 89 (in Russ). 